\title{
Speciation of inorganic phosphorus in some bench-merk soils of Bangladesh
}

\author{
P. Chowdhury ${ }^{1}$, S. Hoque ${ }^{1}$, A. Parvin ${ }^{2}$ and M. Moniruzzaman ${ }^{2 *}$ \\ ${ }^{1}$ Department of soil, water and Environment, University of Dhaka, Dhaka-1000, Bangladesh \\ ${ }^{2}$ Soil and Environment Section, Biological Research Division, BCSIR Laboratories, Dhaka, Bangladesh
}

\begin{abstract}
To study the phosphorus transformation in soils, experiment was conducted in the laboratory. In this study, three different bench-mark soil series of three different Agro-ecological Zones namely, Brahmaputra (Jamuna) floodplains (Dhamrai series, Areni-Eutric gleysols), Low Ganges River Floodplain (Ishurdi series, Chromi-calcaric Gleysols), and Madhupur Tract (Tejgaon series, Chromi-Calcaric Gleysols ) of Bangladesh were selected. For conducting this experiment, all the determination was performed triplicate. The changes of phosphorus fractions were discussed. Soil Phosphorus pools were assessed by sequential P fractionation on days 0, 7, 20 and 40. The inter conversions of different P- fractions were noticed during the course of incubation experiment. The magnitude of these changes differed among soils, being greatest in the Dhamrai soil. Principal component analysis of the data showed that the size of the P pools was related to soil properties; high concentrations of $\mathrm{Ca}-\mathrm{P}$ were associated with high $\mathrm{pH}$ and calcium concentrations, high concentrations of Fe-P and residual $\mathrm{P}$ were correlated with high aluminium. It can be concluded that soil $\mathrm{P}$ pools can be generalized across the three soil used in this study, but that the size of the $\mathrm{P}$ pools is affected by soil properties.
\end{abstract}

Keywords: Speciation; Inorganic pohosphorus

\section{Introduction}

Phosphorus can exist in many different forms in soil, including inorganic and organic, that contribute in varying degrees to the plant-available pool. They are broadly grouped as labile, moderately labile, relatively insoluble, and resistant pools (Hinsiger, 2001). There are two mechanisms that control the $\mathrm{P}$ concentration in the soil solution and the $\mathrm{P}$ movement in soils: solubility of $\mathrm{P}$ containing minerals, and fixation or adsorption of phosphate ions on the surface of soil particles (Holtan et al., 1988). So, the dynamics of phosphorus transformation in the soil system and its fixation and release characteristics have been the subject of numerous investigations but in actual practice the most pertinent issue is to know how much of phosphorus can be made available to the growing crop from the native soil pool (Ghosh and Hasan, 1979). The dynamics of phosphorus transformation in the soil system and its fixation and release characteristics have been the subject of numerous investigation but in actual practice the most important issue is to know how much of phosphorus can be made available to the growing crop from the native soil pool (Ghosh and Hasan, 1979). According to Chang and Jackson (1957), the inorganic phosphates in soils have been classified into easily soluble phosphate (ES - P), aluminium phosphates ( $\mathrm{Al}-\mathrm{P})$, iron phosphates $(\mathrm{Fe}-\mathrm{P})$, reductant soluble phosphates (RS - P) and calcium phosphates $(\mathrm{Ca}-\mathrm{P})$. Phosphorus in adsorbed and/or mineral form is often coated (occluded) by relatively insoluble oxides and hydroxides of Fe and Al. Neutral and slightly acid soils usually contain all five fractions in comparable amounts. Alkaline and calcareous soils are often dominant in $\mathrm{Ca}-\mathrm{P}$ the increase in any one fraction occurs at the expense of other inorganic fractions (Sah and Mikkelsen, 1986). The main objectives of this study were to have a comprehensive understanding of soil properties interactions such as $\mathrm{pH}$ with changes in $\mathrm{P}$ status using conceptual $\mathrm{P}$ pools of soils of Dhamrai, Ishurdi and Tejgaon series.

\section{Materials and methods}

\section{Experimental setup}

The surface soil samples $(0-15 \mathrm{~cm})$ were collected from Dhamrai, Ishurdi and Tejgaon series. The soils were air-dried and ground to pass through a $2 \mathrm{~mm}$ sieve. The ground samples were preserved for analyses. Measurements of selected physical and chemical properties of the soils were carried out in triplicate according to conventional methods. Data of the physical and chemical analysis are presented in Table 1 .

Before the experiment, an incubation study at a temperature of $24^{\circ} \mathrm{C} \pm 2^{\circ} \mathrm{C}$ was carried out in the laboratory. Ten gram soil was taken in a $50 \mathrm{ml}$ beaker. Beakers were covered by

\footnotetext{
*Corresponding author e-mail: monirbcsir@gmail.com
} 
parafilm to maintain moisture at field condition. Soil samples after $0,7,20$ and 40 days of incubation were placed in centrifuge tubes. These soils were analyzed for fractionation of inorganic $\mathrm{P}$ fractions following Chang and Jackson (1957).

\section{Analyses}

Particle size analysis of the soil samples was done by hydrometer method as described by Gee and Bauder (1986). Textural classes were determined by Marshall's Triangular co-ordinate system. Soil pH was measured (field condition) electrochemically by using glass electrode $\mathrm{pH}$ meter and the ratio of soil to water was 1:2.5 (Jackson 1973). Cation exchange capacity (CEC) of soils was determined using neutral $1 \mathrm{~N} \mathrm{NH}_{4} \mathrm{OAc}$ solution as described by Schollenberger and Simon (1945).

The organic carbon of the soil samples was determined by wet - oxidation method as outlined by Walkley and Black (1934). Soil organic matter was calculated by multiplying the percent value of organic carbon by the conversion factor of 1.724. Total nitrogen was determined by micro Kjeldahl's method as described by Jackson (1973).

Soil samples were digested with $\mathrm{HNO}_{3}-\mathrm{HClO}_{4}(2: 1)$ mixture as described by Piper (1950) for the determination of total $\mathrm{P}, \mathrm{K}$ and $\mathrm{S}$. Total acid digested potassium was determined by using Flame Photometer (Model: Jenway, PFP7) at $769 \mathrm{~nm}$ wavelength. Total Phosphorus was determined by vanadomolybdate yellow color method using UV-Visible Spectrophotometer (Model: Analytik jena Specord 205) as described by Jackson (1973). Total sulfur was determined by turbidimetric method (Hunt, 1980).
The concentrations of various $\mathrm{P}$ pools were determined by sequential $\mathrm{P}$ fractionation (Chang and Jackson, 1957) with some modifications. $25 \mathrm{ml} 1 \mathrm{M} \mathrm{NH}_{4} \mathrm{Cl}$ was added in $0.5 \mathrm{gm}$ soil sample in $50 \mathrm{ml}$ centrifuge tubes, shaked $30 \mathrm{~min}$, centrifuged and collected supernatant. Then $25 \mathrm{ml} 0.5 \mathrm{M}$ $\mathrm{NH}_{4} \mathrm{~F}$ ( $\mathrm{pH}$ 8.2) was added to the residue, shaked $1 \mathrm{~h}$, centrifuged, collected supernatant, washed twice with 12-15 $\mathrm{ml}$ saturated $\mathrm{NaCl}$ and combined the washings to the extract. After that, $25 \mathrm{ml}$ of $0.1 \mathrm{M} \mathrm{NaOH}$ was added to the soil residue and shaked for $17 \mathrm{~h}$. Then the suspension was centrifuged and decanted the surpantant. Approximately $25 \mathrm{ml}$ of $0.5 \mathrm{~N}$ $\mathrm{H}_{2} \mathrm{SO}_{4}$ was added to the soil residue and shaked for $1 \mathrm{~h}$. Then it was centrifuged for $10 \mathrm{~min}$ and decanted the supernatant. The soil was washed twice with $12.5 \mathrm{ml}$ saturated $\mathrm{NaCl}$, and centrifuged. The washings was combined with the extract. Then $20 \mathrm{ml}$ of $0.3 \mathrm{M}$ sodium citrate and $0.5 \mathrm{~g}$ of $\mathrm{Na}_{2} \mathrm{~S}_{2} \mathrm{O}_{4}$ was added, stired rapidly and shaked for 5 minutes. The suspension was heated in a water bath at $75^{\circ} \mathrm{C}$ to $80^{\circ} \mathrm{C}$ with constant shaking for 15 minutes and centrifuged. The supernatant solution was collected in $50 \mathrm{ml}$ volumetric flask and diluted to $50 \mathrm{ml}$ with deionized water. The soil was washed twice with $12-15 \mathrm{ml}$ saturated $\mathrm{NaCl}$ and centrifuged. After that, $25 \mathrm{ml}$ of $0.1 \mathrm{M} \mathrm{NaOH}$ was added to the soil residue and shaked for $17 \mathrm{~h}$. The suspension was centrifuged and decanted the supernatant. Again, the soil was washed twice with $12-15 \mathrm{ml} \mathrm{NaCl}$ and combined with extract. Inorganic phosphorus was determined by ascorbic acid blue colour method of Murphy and Riley (1962).

\section{Results and discussion}

The findings of the experiments are showed that most of the fractions of $\mathrm{P}$ decreased at the earlier period ( 0 - 7 days $)$ which might be due to sorption and interconversion of the

Table I. Physical and chemical properties of the soils

\begin{tabular}{lccc}
\hline Properties & \multicolumn{3}{c}{ Soil Series } \\
\cline { 2 - 4 } & Dhamrai series & Ishurdi series & Tejgaon series \\
\hline Sand $(\%)$ & 11.04 & 3.74 & 6.88 \\
Silt $(\%)$ & 65.8 & 54.41 & 51.52 \\
CIay $(\%)$ & 23.16 & 41.85 & 41.60 \\
Textural Class & Silty loam & Silty clay loam & Silty clay loam \\
pH & 6.10 & 8.13 & 4.99 \\
OC $(\%)$ & 1.09 & 1.25 & 1.29 \\
Organic Matter $($ OM)\% & 1.88 & 2.16 & 2.22 \\
Total N $(\%)$ & 0.19 & 0.15 & 0.13 \\
Total P $(\%)$ & 0.072 & 0.061 & 0.048 \\
Total K $(\%)$ & 0.237 & 0.91 & 0.32 \\
Total S $(\%)$ & 0.035 & 0.025 & 0.075 \\
Cation Exchange Capacity $(\mathrm{CEC})(\mathrm{cmole} / \mathrm{kg})$ & 13.57 & 10.71 & 9.29 \\
\hline
\end{tabular}


fractions during this period and mineralization increased their concentrations. The change with time indicated immobilization at the earlier periods (between 7 and 20 days) and mineralization beyond 40 days. Initial sorption was noticed in Dhamrai, Ishurdi and Tejgaon soils, followed by release and consequently an increasing trend was noticed with time of incubation.

\section{Easily soluble phosphorus}

The easily soluble $\mathrm{P}$, extracted with $25 \mathrm{ml} 1 \mathrm{M} \mathrm{NH} \mathrm{Nl}_{4}$ first increased up to 7 days, decreased sharply up to 20 days and then slightly increased after 40 days in most of the soils. The value of it was ranged between 2.54 and 10.48, 1.61 and 8.45, 0.51 and $8.06 \mu \mathrm{g} / \mathrm{g}$, respectively, in Dhamrai, Ishurdi and Tejgaon soil. The highest value of $10.48 \mu \mathrm{g} / \mathrm{g}$ was noticed in case of Dhamrai soil at the end of 7 days of incubation (Fig. 1). Summarizing the results obtained in some Indian soils, Kothandaraman and Krishnamoorthy (1979) stated that easily soluble P ranges from 0 to $79 \mu \mathrm{g} / \mathrm{g}$. Alluvial soils were high (average $22 \mu \mathrm{g} / \mathrm{g}$ ) followed by red soils $(11 \mu \mathrm{g} / \mathrm{g})$ while black and Laterite soils were very low in this P fraction. In the present study, Dhamrai series being an alluvial soil also contained the highest value of $10.48 \mu \mathrm{g} / \mathrm{g}$. Tejgaon series belonged to red soil having a $\mathrm{pH}$ of 4.99 contained the 8.06 $\mu \mathrm{g} / \mathrm{g}$.

\section{Aluminium bound phosphorus $(A l-P)$}

Data presented in Fig. 2. indicated that the Al-P contents of all the soils changed with time of incubation. Aluminium phosphate contents decreased appreciably within 7 days of incubation. Al - P ranged between 40.44 and 82.19, 73.29 and 77.94 , and 76.73 and $84.31 \mu \mathrm{g} / \mathrm{g}$ at the time of incubation, respectively in Dhamrai, Ishurdi and Tejgaon series. In Tejgaon series the values decreased up to 7 days of incubation and then increased with time. But in Dhamrai and Ishurdi series, the $\mathrm{Al}$ - $\mathrm{P}$ first decreased up to 7 days, increased up to 20 days and then the decrease continued slowly up to 40 days and lowered corresponding to the values obtained at the end of 7 days of incubation in Dhamrai series and Ishurdi series. The values found in this investigation were within the range as reported by Kothandaraman and Krishnamoorthy (1979). They stated that a wide variation was noted in the $\mathrm{Al}$ - $\mathrm{P}$ fraction and the values ranged from 2 to $213 \mu \mathrm{g} / \mathrm{g}$ with a mean value of $42 \mu \mathrm{g} / \mathrm{g}$. This fraction found in Bangladesh soils were 16 to $174 \mu \mathrm{g} / \mathrm{g}$ (Islam and Khan, 1966)

\section{Iron bound phosphorus $(\mathrm{Fe}-\mathrm{P})$}

The changes in iron phosphate $(\mathrm{Fe}-\mathrm{P})$ contents of the soils at different time intervals are presented in Figure 3. The data indicated that the $\mathrm{Fe}$ - $\mathrm{P}$ contents of all the soils decreased for a period and then increased up to 40 days of incubation. Marked changes were observed in Tejgaon and Dhamrai series. After 40 days of incubation, the value of $\mathrm{Fe}-\mathrm{P}$ contents of Tejgaon soils was recorded highest. In Ishurdi series, very little change was occurred between 7 and 40 days and slightly increased appreciably with time (26.95 to $29.02 \mu \mathrm{g} / \mathrm{g}$ ). At the time of incubation, the lowest and highest values were 141.23 and $224.03 \mu \mathrm{g} / \mathrm{g}$, respectively in Tejgaon series; the lowest value of $46.99 \mu \mathrm{g} / \mathrm{g}$ and the highest value of $129.79 \mu \mathrm{g} / \mathrm{g}$ in Dhamrai series; and in Ishurdi series, the lowest value was $26.95 \mu \mathrm{g} / \mathrm{g}$ and the highest value was 30.31 $\mu \mathrm{g} / \mathrm{g}$. It is evident from the results that $\mathrm{Fe}-\mathrm{P}$ is the dominant fraction in Tejgaon series $(\mathrm{pH} 4.99)$ due to its acidic condition but in Ishurdi series ( $\mathrm{pH} 8.13)$ this fraction was found to be very low due to its calcareous nature. This is in conformity with the reports of Islam and Khan (1966), Patiram et al., (1990), and Rokima and Prasad (1991). For Bangladesh soils Islam and Khan (1966), Ahmed and Islam (1975), Mandal and Islam (1978), observed that values of this fraction varied from 10 and $170 \mu \mathrm{g} / \mathrm{g}$. Kothandaraman and Krisnamoorthy (1979) reported that the content of $\mathrm{Fe}-\mathrm{P}$ showed a wide variation ranging from 1 to $420 \mu \mathrm{g} / \mathrm{g}$ with a mean value of $41 \mu \mathrm{g} / \mathrm{g}$. Laterite soils recorded the highest value.

\section{Calcium bound phosphorus $(\mathrm{Ca}-\mathrm{P})$}

Changes in $\mathrm{Ca}-\mathrm{P}$ with time of incubation were different in different soils. In the Fig. $4, \mathrm{Ca}-\mathrm{P}$ at 7 days of incubation ranged between 2.6 and 40.47, 175.43 and 367.4, and 206.5 and $650.3 \mu \mathrm{g} / \mathrm{g}$ in Tejgaon, Dhamrai and Ishurdi series, respectively. The $\mathrm{Ca}-\mathrm{P}$ contents decreased appreciably within 7 days of incubation in Dhamrai and Ishurdi series and after 7 days the $\mathrm{Ca}$ - $\mathrm{P}$ contents increased up to 20 days then decreased again. In case of Tejgaon series, there was a definite trend of changes, but in little amount. The highest values were obtained at the end of 20 days of incubation and it was $650.3 \mu \mathrm{g} / \mathrm{g}$ in Ishurdi series. In contrast the value was only $40.47 \mu \mathrm{g} / \mathrm{g}$ at 20 days of incubation in Tejgaon series. Islam and Khan (1966) reported that $\mathrm{Ca}$ - P content decreased with time at field moisture capacity of the soils. The values ranged between 50 and $350 \mu \mathrm{g} / \mathrm{g}$ for soils of Bangladesh (Islam and Khan 1966; Ahmed and Islam 1975; Mandal and Islam, 1978). A major fraction of $\mathrm{P}$ was bound with $\mathrm{Ca}$ in Ishurdi series ( $\mathrm{pH} 8.13)$ because of the calcareous nature of the soil. Similar results were reported by Tomar et al., (1984). Chang and Chu (1961) observed that $\mathrm{Ca}$ - P formation was relatively higher in soils of higher $\mathrm{pH}$ values. Raju and Rao 
(1979) also reported that in acid soils $\mathrm{Ca}$ - P is comparatively less than that of $\mathrm{Fe}$ - P ranging between 18 to $199 \mu \mathrm{g} / \mathrm{g}$ in the different treatments. Since $\mathrm{Fe}$ and $\mathrm{Al}$ ions are dominant in acid soils, the activity of $\mathrm{Ca}$ ions is low and hence the amount of $\mathrm{Ca}-\mathrm{P}$ is comparatively low. Similar finding was also obtained with acid soil of Tejgaon series.

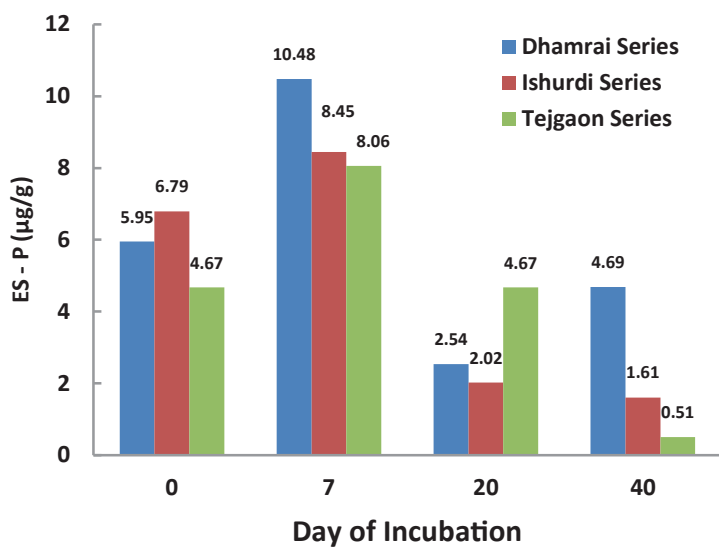

Fig. 1. Changes in Easily Soluble Phosphorus (ES - P) content of the soils

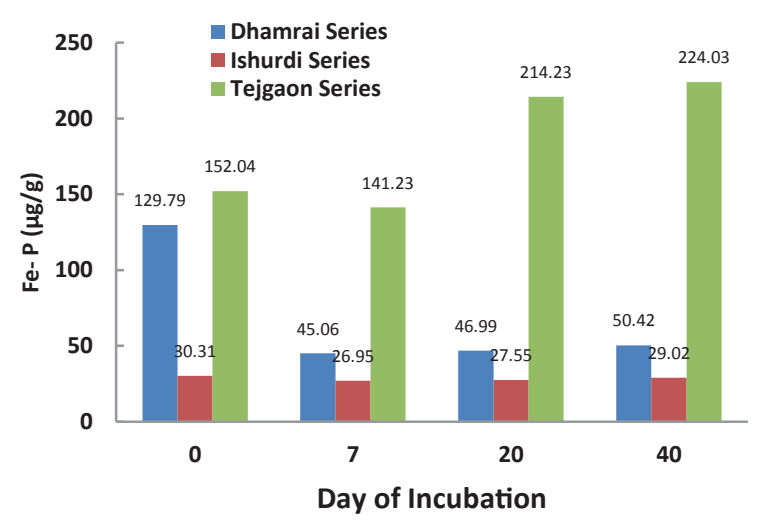

Fig. 3. Changes in Iron bound Phosphorus (Fe P) content of the soils

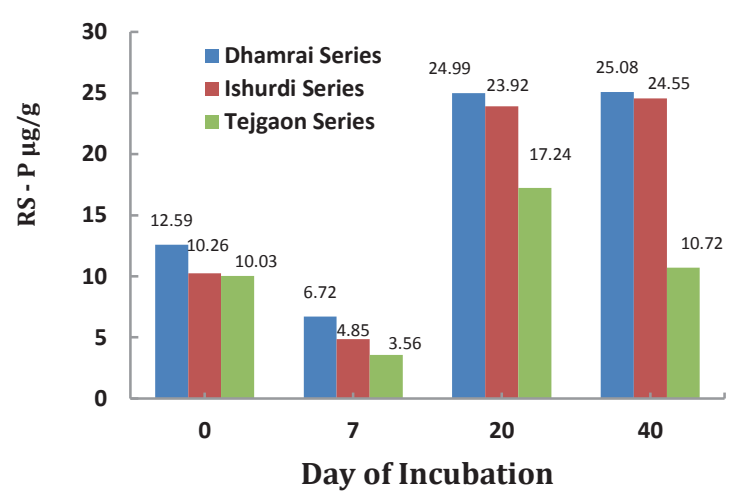

Fig. 5. Changes in Reductant Soluble Phosphorus (RS - P) content of the soils

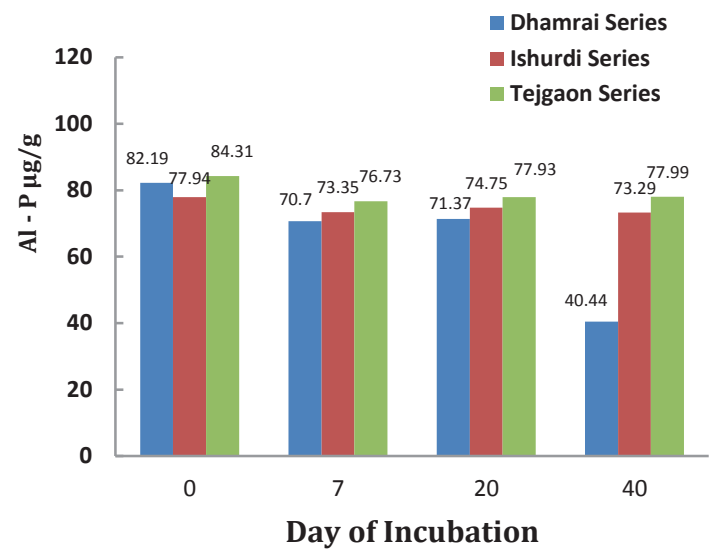

Fig. 2. Changes in Aluminium bound Phosphorus (Al - P) content of the soils

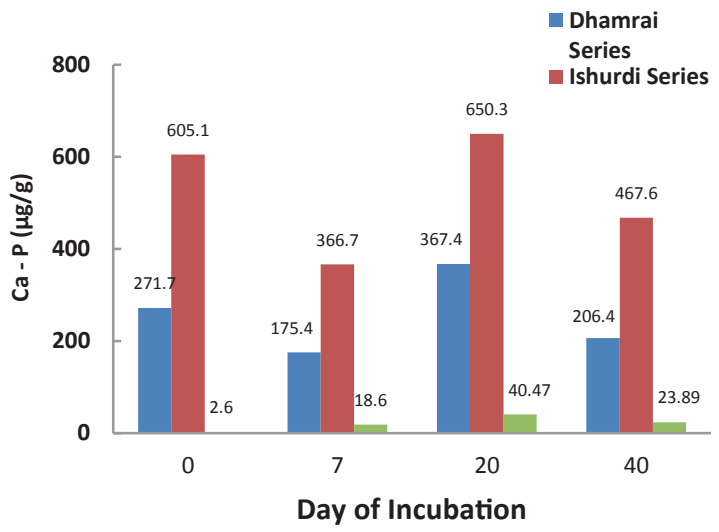

Fig. 4. Changes in Calcium bound Phosphorus (Ca - P) content of the soils

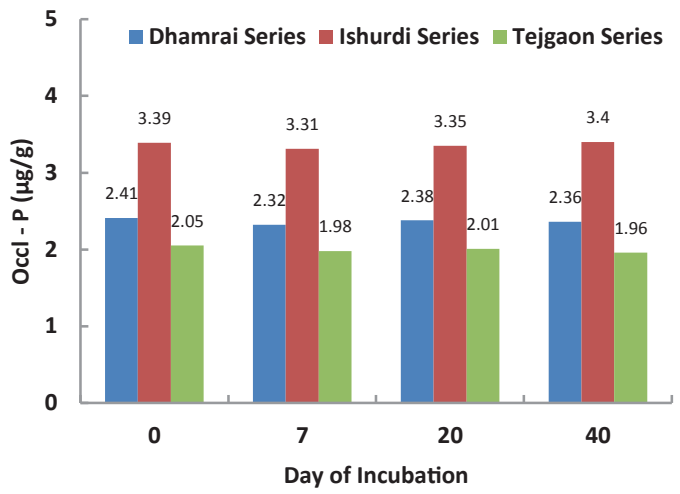

Fig. 6. Changes in Occluded Phosphorus (Occl P) content of the soils 


\section{Reductant soluble phosphorus $(R S-P)$}

The changes in citrate - dithionate extractable $\mathrm{P}$, which is known as reductant soluble phosphate (RS - P), with time of incubation showed different behavior in different soils. The highest values were $25.08 \mu \mathrm{g} / \mathrm{g}$ in Dhamrai series, obtained at the end of 40 days of incubation and in Ishurdi series and in Tejgaon series, it was $24.55 \mu \mathrm{g} / \mathrm{g}$ and $10.72 \mu \mathrm{g} / \mathrm{g}$, also obtained at the end of 40 days of incubation.

\section{Occluded phosphorus $(\mathrm{Occl}-\mathrm{P})$}

Occluded - P fraction was more or less similar in all the soils under investigation irrespective of $\mathrm{pH}$ values. The Occl - $\mathrm{P}$ is the most weathering resistant form and accumulates during the several centuries of time. Occl - P was not greatly affected by incubation periods. Genetic factor primarily affect the content of these $\mathrm{P}$ fractions. These results were in conformity with the observation made by Islam and Khan (1966), Raju and Rao (1979). Islam and Khan (1966) reported that Occl $\mathrm{P}$ measured during the period of 12 weeks at field moisture capacity did not indicate any appreciable increase or decrease.

The results obtained through this experiment revealed that there was a marked variation in the forms of $\mathrm{P}$ in the cultivated layer of the 3 different soils viz. Dhamrai, Ishurdi and Tejgaon series. The acid soils (Tejgaon) are rich in $\mathrm{Fe}-$ $\mathrm{P}$, but poor in $\mathrm{Ca}$ - P. Calcium - $\mathrm{P}$ dominated in calcareous soil (Ishurdi). In Dhamrai and Ishurdi series, the major inorganic fractions were found in the order $\mathrm{Ca}-\mathrm{P}>\mathrm{Fe}-\mathrm{P}>\mathrm{Al}-\mathrm{P}$. The high amount of $\mathrm{Ca}-\mathrm{P}$ might be due to high $\mathrm{pH}$. Rokima and Prasad (1991) reported that in calcareous soil, most of the added $\mathrm{P}$ appeared to be retained as $\mathrm{Ca}-\mathrm{P}$. All different fractions steadily increased with increasing doses of fertilizers were also reported by Rokima and Prasad (1991). Working with acid soils of India, Patiram et al. (1990) stated that among the forms of $\mathrm{P}, \mathrm{Fe}-\mathrm{P}$ is dominant, being approximately 1.5 times than $\mathrm{Al}-\mathrm{P}$ or $\mathrm{Ca}-\mathrm{P}$. But $\mathrm{Al}-\mathrm{P}$ and $\mathrm{Ca}$ - P did not differ much. Their observation is corroborated with the present investigation. Pattanayak and Misra (1989), reported that increase in inorganic $\mathrm{P}$ fractions was because of transformation of a portion of organic $\mathrm{P}$ into inorganic form due to hydrolysis of organic matter.

Distribution of inorganic phosphates in different fractions follows the following sequences - In Dhamrai Series $(\mathrm{pH}$ 6.1), $\mathrm{Ca}-\mathrm{P}>\mathrm{Fe}-\mathrm{P}>\mathrm{Al}-\mathrm{P}>\mathrm{RS}-\mathrm{P}>\mathrm{ES}-\mathrm{P}>\mathrm{Occl}-\mathrm{P}$; in Tejgaon series ( $\mathrm{pH}$ 4.99), $\mathrm{Fe}-\mathrm{P}>\mathrm{Al}-\mathrm{P}>\mathrm{RS}-\mathrm{P}>\mathrm{Ca}-\mathrm{P}>$ $\mathrm{ES}-\mathrm{P}>\mathrm{Occl}-\mathrm{P}$ and in Ishurdi series ( $\mathrm{pH}$ 8.13), $\mathrm{Ca}-\mathrm{P}>\mathrm{Al}$ - P > RS - P > Fe - P > ES - P > Occl - P. In this experiment, residual $\mathrm{P}$ fractions, calculated from the difference between total $\mathrm{P}$ and inorganic $\mathrm{P}$ showed that these fractions together were higher in Tejgaon series $(53.18 \%)$ followed by Ishurdi $(52.37 \%)$ and Dhamrai (17.9\%) series.

\section{Conclusion}

It may be concluded from the results of the incubation experiment that phosphorus was converted mainly to ES - P, $\mathrm{Ca}$ - P, Al - P and Fe - P with time. These fractions rearranged among themselves depending on the nature of the soils during this time. Iron - $\mathrm{P}$ is the dominant fraction in Tejgaon soil ( $\mathrm{pH} 4.99)$ and $\mathrm{Ca}-\mathrm{P}$ is the major fraction in Dhamrai (pH 6.1) and Ishurdi ( $\mathrm{pH} 8.13$ ) soils. Available P, extracted by Chang and Jackson methods, were significant and higher values were obtained with corresponding incubation periods.

\section{Reference}

Ahmed B and Islam A (1975), Extractable phosphate in relation to the forms of phosphate fractions in some humid tropical soils, Tropical Agriculture 52: 113-118.

Chang SC and Jackson ML (1957), Fractionation of soil phosphorus, Soil Science Journal 84: 133-144.

Chang SC and Chu WK (1961), The late of soluble phosphates applied to soils, Journal of Soil Science 12: 286 - 293.

Gee GW and Bauder JW (1986), Particle size analysis In: Methods of Soil Analysis. Part 1, Ed. Klute, American Society of Agronomy and Soil Science Society of America, Madison, WI, pp 383-411.

Ghosh AB and Hasan R (1979), Phosphorus Fertility Status of the Soils of India, Bulletin of Indian Society of Soil Science 12: 1-8.

Hinsinger P (2001), Bioavailability of soil inorganic P in the rhizosphere as affected by root - induced chemical changes: a review, Jounal of Plant and Soil 237: 173-195.

Holtan HL, Kamp-Nielsen and Stuanes AO (1988), Phosphorus in soil, water and sediment: an overview, Hydrobiologia Journal 170: 19 - 34.

Hunt J (1980), Determination of total sulfur in small amount of plant material, Analyst 105: 83-85.

Islam A and Khan TH (1966), Transformation of different phosphatic fertilizers in soils of East Pakistan at field moisture capacity and waterlogged conditions, Proceeding Pakistan Academic Science 5(1): 63-71.

Jackson ML (1973), Soil Chemical Analysis, Prentice Hall of India Pvt. Ltd, New Delhi. 
Kothandaraman GV and Krishnamoorhty KK (1979), Forms of inorganic phosphorus in Tamil Naidu soils, Bulletin of Indian Society of Soil Science 12: 243 - 248.

Mandal R and Islam A (1978), Vertical distribution of phosphate in some sub humid tropical soils of Bangladesh, Dacca University Studies XXVI(2): 39- 51 .

Murphy J and Riley JP (1962), A modified single solution method for the determination of phosphate in natural waters, Analytical Chimica Acta 27: 31 - 36.

Patiram RN, Raj MM and Prasad RN (1990), Forms of soil phosphorus and suitable extactants for available phosphorus in acid soils of Sikkim, Indian Society of Soil Science Journal 38(1): 237 - 242.

Pattanayak SK and Misra UK (1989), Transformation of phosphorus in some acid soils of Orissa, Indian Society of Soil Science Journal 37: 455 - 460.

Piper CS (19500, Soil and plant analysis, University of Adealaide Press, Australia.

Raju T and Venkata Rao BV (1979), Influence of long term phosphate fertilizer application on forms of phosphorus in coffee soils, Bulletin of Indian Society of Soil Science 12: 233 - 235.
Rokima J and Prasad B (1991), Integrated Nutrient Management: II. Transformation of applied P into inorganic $\mathrm{P}$ fractions in relation to its availability and uptake in calcareous soil, Jounal of Indian Society of Soil Science 39(4): 703 - 710.

Sah RN and Mikkelsen DS (1986), Transformation of inorganic phosphorus during the flooding and draining cycles of soil, Soil Science Society of America Journal 50: $62-67$.

Schollenberger CJ and Simon RH (1945), Determination of exchange capacity and exchangeable bases in soil, Ammonium acetate method, Soil Science 59: 13-24.

Tomar NK, Khanna SS and Gupta AP (1984), Transformation of phosphates varying in citrate and water solubility in a calcareous soil after incubation with cattle dung, Jounal of Indian Society of Soil Science 32: 421-426.

Walkley A and Black IA (1934), An examination of Degtjareff method for determining soil organic matter and a proposed modification of the chromic acid titration method, Soil Science 37: 29 - 37. 